Research Article

\title{
Experimental Investigation on Effects of Bacterial Concentration, Crack Inclination Angle, Crack Roughness, and Crack Opening on the Fracture Permeability Using Microbially Induced Carbonate Precipitation
}

\author{
Yulin Zou, ${ }^{1,2}$ Hao Bai $\mathbb{D}^{3},{ }^{3}$ Fan Shen, ${ }^{4}$ Hong Xu, ${ }^{5}$ and Yundong Shou $\mathbb{D D}^{5,6}$ \\ ${ }^{1}$ Sichuan Railway Investment Group Co., Ltd., Chengdu 100036, China \\ ${ }^{2}$ Sichuan Yanjiang Panning Expressway Co., Ltd., Panzhihua 617000, China \\ ${ }^{3}$ Sichuan Expressway Construction \& Development Group Co., Ltd., Chengdu, China \\ ${ }^{4}$ School of Civil Engineering, Wuhan University, Wuhan 430072, China \\ ${ }^{5}$ National Breeding Base of Technology and Innovation Platform for Automatic-Monitoring of Geologic Hazards \\ (Chongqing Engineering Research Center of Automatic Monitoring for Geological Hazards), Chongqing 400042, China \\ ${ }^{6}$ Guizhou Provincial Key Laboratory of Rock and Soil Mechanics and Engineering Safety, Guiyang 550025, China
}

Correspondence should be addressed to Hao Bai; secdcbh@126.com and Yundong Shou; syd6188@163.com

Received 25 April 2021; Accepted 23 June 2021; Published 7 July 2021

Academic Editor: Yunteng Wang

Copyright (c) 2021 Yulin Zou et al. This is an open access article distributed under the Creative Commons Attribution License, which permits unrestricted use, distribution, and reproduction in any medium, provided the original work is properly cited.

Uncontrollable leakage has significant effects on the safety of fractured rock mass, and microbially induced carbonate precipitation (MICP) is an effective way to control the seepage. In this study, four sets of seepage experiments are conducted on transparent rock-like specimens containing MICP filled single cracks to investigate the effects of bacterial concentration, crack inclination angle, crack roughness, and crack opening on fracture permeability. The experimental results show that calcium carbonate precipitation is produced when Sporosarcina pasteurii and cementing fluid are injected into the cracks, which can seal the cracks and reduce the permeability of the cracks. Moreover, the calcium carbonate produced by Sporosarcina pasteurii increases with increasing bacterial concentration. Furthermore, the fracture permeability of the MICP filled crack increases first and then decreases with increasing inclination, roughness, and opening of cracks. The experimental results provide a better understanding of the influence of different construction conditions on fracture permeability when the MICP technology is applied in rock engineering.

\section{Introduction}

As an important part of engineering rock mass, cracks affect not only the integrity and stability of rock mass, but also cause the seepage disaster in rock engineering [1-12]. Cracks in rock mass provide the flow channels for groundwater in rock engineering, which lead to water disasters, and cause huge casualties and property losses [13], such as dam collapse of Malpasset Reservoir in France [14], bank collapse of Vajont Reservoir in Italy [15], instability of Libby abutment in the United States [16], and water inrush from various roadways [17]. Therefore, it is necessary to strengthen the surrounding rock with fissures in rock engineering.

Cementitious and chemical grouts are commonly employed to improve the permeability strength by sealing the cracks in fractured rock mass [18]. However, those grout materials may contribute risk to environmental or human health by poisoning the groundwater in functional aquifers [19]. In addition, the viscosity of cement grout is high so that the cement grout cannot be injected to intact rock, which has restricted its limitation of application. Moreover, the expensive cost and low life of chemical grouts seriously restrict extension and utilization of the technology [20]. To 
overcome those limitations of cementitious and chemical grouts, a new grouting method, microbially induced carbonate precipitation (MICP), has been developed based on microorganisms [21]. The MICP is a novel grouting technology with the advantages of low viscosity, low pressure, and environmental friendliness [22]. Sporosarcina pasteurii, which is a common non-pathogenic and aerobic bacterium, is adopted to generate the cementing agent of $\mathrm{CaCO}_{3}$ to plug the flow paths in fractured rock mass. The MICP process involves a sequence of biochemical reactions that can be divided into two stages. First, Sporosarcina pasteurii secretes urease during its growth, and the urea in fissure water is broken down to bicarbonate ions by urease. Second, calcium carbonate precipitation is obtained by the chemical reaction between bicarbonate ions and calcium ions from the calcium salts. Then, the biochemical reaction in the MICP process can be written as follows [23, 24]:

$$
\begin{gathered}
\mathrm{CO}\left(\mathrm{NH}_{2}\right)_{2}+2 \mathrm{H}_{2} \mathrm{O} \stackrel{\text { urease }}{\longrightarrow} \mathrm{CO}_{3}^{2-}+2 \mathrm{NH}_{4}^{+} \\
\mathrm{Ca}^{2+}+\mathrm{CO}_{3}^{2-} \longrightarrow \mathrm{CaCO}_{3} \downarrow
\end{gathered}
$$

Since the product of the MICP process, $\mathrm{CaCO}_{3}$, is a kind of high-strength calcium salts, which is durable in alkaline environments, MICP can be employed in strengthening soil mass. Many scholars have carried out extensive research on MICP strengthening soil mass [24-30], and the results showed that MICP can increase uniaxial compressive strength of soils and can significantly decrease the water permeability of soils. Furthermore, a series of laboratory and field tests on the effect of fractures sealed in rock mass have been conducted using the MICP technology. Ferris et al. [31] applied the MICP technology in porous media, and they found that calcium carbonate can be used as a plugging agent and binder to control the flow of water in rock mass. Cuthbert et al. [32] applied the MICP technology to fractured rock mass through a model experiment and theoretical deduction. The results showed that the permeability of fractured rock mass can be reduced very well, which provide a new idea for crack seepage resistance. Moreover, Phillips et al. [33] used the MICP technology to treat fractured sandstone, and they found that the permeability of the treated samples is decreased by 2 to 4 orders of magnitude, which can be used to mitigate the potential of $\mathrm{CO}_{2}$ leakage. The experimental results obtained by Bucci et al. [34] showed that the permeability of the cracks in an artificially fractured sandstone specimen is decreased by $80 \%$ after the MICP method is used, especially at the top and bottom of the cracks. Mountassir et al. [35] studied the effect of crack width and opening on the filling process of MICP, and the results showed that the treated crack size decreased and the crack permeability is decreased after the MICP method is used. Tobler et al. [36] studied the effect of MICP on sandstone and fractured media, and they found that the permeability of samples treated by MICP is greatly reduced, and the shear resistance of filled cracks is increased. Wu et al. $[37,38]$ investigated the distribution and filled state of MICP in fissures by means of model experiments, and they analyzed the permeability of cracks after filling using a numerical simulation. The results showed that calcium carbonate was mainly concentrated near the injection port, and a semiempirical formula was proposed to evaluate the decrease of fissure permeability. Minto et al. [20] investigated the influence of fluid velocity on the distribution of calcium carbonate. They found that calcium carbonate can precipitate in large quantities and the precipitation amount and location can be controlled by the flow rate.

Experimental results showed that microbially induced carbonate precipitation can be successfully applied in grouted cracks to seal the flow paths. However, many external factors, such as bacterial concentration, fracture inclination angle, crack roughness, and fracture aperture, are involved in practical engineering, which have not been studied. Therefore, this experiment studies these factors through the design of grouting device and processing of prefabricated crack samples, aiming to provide some reference for practical engineering.

\section{Sporosarcina pasteurii}

2.1. Bacterial Culture. In this paper, Sporosarcina pasteurii purchased from American Type Culture Collection (No. ATCC 11859) are selected as the bacteria to secrete urease. They are aerobic Gram-positive bacteria which grow in alkaline environment and show optimal growth at $25^{\circ} \mathrm{C} \sim 37^{\circ} \mathrm{C}$. Bacteria are cultured on CASO + urea medium; the component and dosage of the culture medium are shown in Table 1 . The culture medium is sterilized at $121.3^{\circ} \mathrm{C}$ for 20 minutes in a pressure pot, and then after cooling, urea is added to the culture medium by filtration sterilization. In addition, the $\mathrm{pH}$ (pondus hydrogenii) value of the culture medium is adjusted to 7.3 with $1 \mathrm{~mol} / \mathrm{L} \mathrm{NaOH}$ solution during culturing. Finally, the culture medium is incubated at $30^{\circ} \mathrm{C}$ on an orbital shaker at $200 \mathrm{rpm}$ for approximately $48 \mathrm{~h}$, and then the bacteria can be clearly observed in the medium as shown in Figure 1.

Bacteria absorb or scatter at a specific wavelength, and the concentration of bacteria is proportional to the amount of light absorbed. Therefore, bacterial concentration can be measured through the absorbance (turbidimetry) method. The optical density of bacteria at $600 \mathrm{~nm}$ wavelength determined by ultraviolet-visible spectrophotometer is used to measure the concentration of bacteria in present experiment. Figure 2 shows growth curve of bacteria. It can be found from Figure 2 that the optical density of bacteria at $600 \mathrm{~nm}$ wavelength grows slowly in 0-3 hours because bacteria need to adapt to the new environment, which leads to the decrease of reproduce. As the bacteria adapt to the new culture medium environment, OD grows rapidly in 3-24 hours and enters logarithmic growth period. Finally, the concentration of bacteria gradually stabilizes in 24-48 hours, and the OD value of bacterial solution gradually stabilizes to 2.25 .

The rate of urea hydrolysis caused by urease is termed as the urease activity which can be determined by measuring the change rate of solution electroconductivity [26]. To determine the urease activity of bacterial suspension, $2 \mathrm{ml}$ 
TABLE 1: CASO medium components.

\begin{tabular}{lcccccc}
\hline Reagent name & Peptone from soymeal $(\mathrm{g})$ & Peptone from casein $(\mathrm{g})$ & Urea $(\mathrm{g})$ & $\mathrm{NaCl}(\mathrm{g})$ & Agar $(\mathrm{g})$ & Deionized water $(\mathrm{L})$ \\
\hline Liquid medium & 5 & 15 & 20 & 5 & - & 1 \\
Solid medium & 5 & 15 & 20 & 5 & 20 & 1 \\
\hline
\end{tabular}

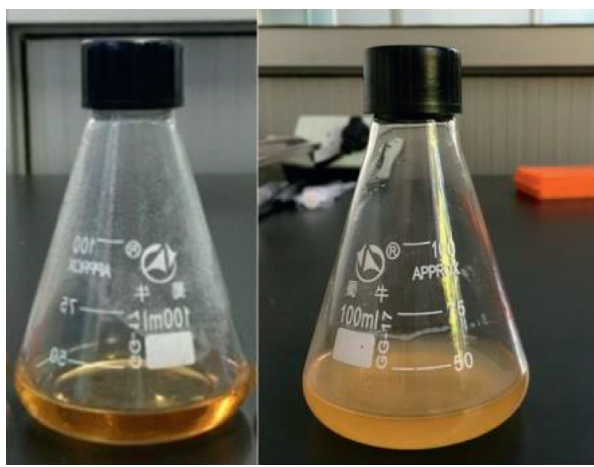

(a)

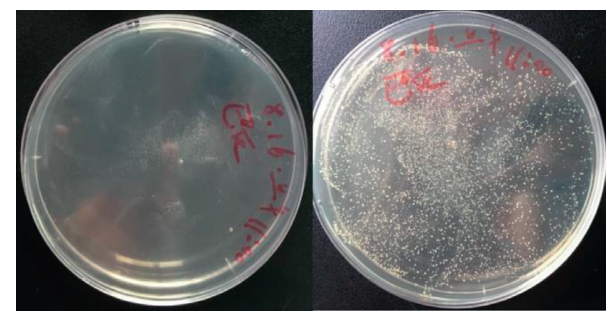

(b)

Figure 1: The appearance of Sporosarcina pasteurii in (a) liquid medium and (b) solid medium.

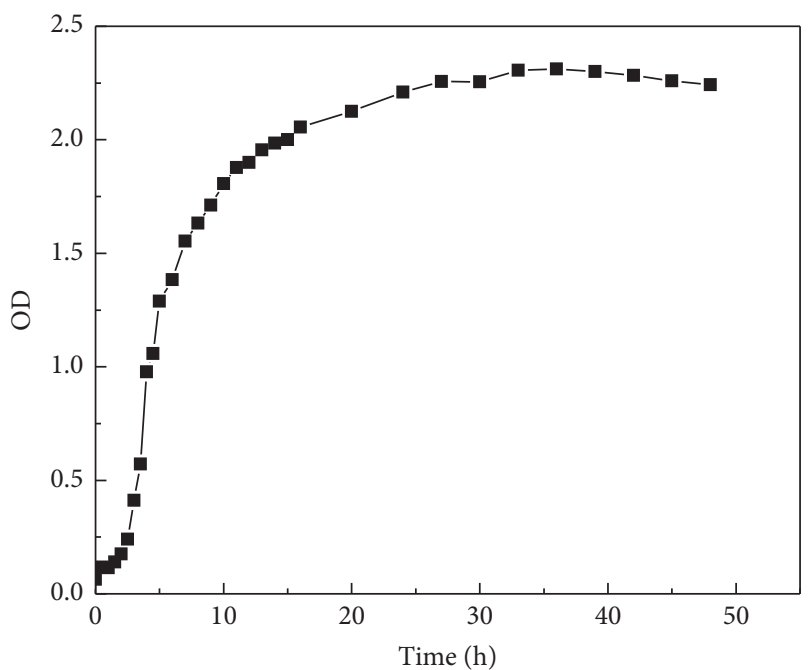

FIgURE 2: Variations in bacterial concentration with time.

bacterial solution is added to $18 \mathrm{ml} 1 \mathrm{~mol} / \mathrm{L}$ urea solution and the change in electroconductivity is monitored over $5 \mathrm{~min}$ as nonionic urea is hydrolyzed producing ionic ammonia. Then, the urease activity can be expressed as

$$
k_{\text {urease }}=\frac{10 c \Delta E}{\Delta t}
$$

where $k_{\text {urease }}$ is the urease activity, $\Delta E$ is the change in electroconductivity between measurements, $\Delta t$ is the time interval between measurements, 10 is dilution factor, and $c$ is the coefficient between the change of electroconductivity and the amount of urea hydrolysis [25].

Figure 3 shows the variations in the bacterial urease activity in solution. It is found from Figures 2 and 3 that the changes of bacterial concentration and urease activity are

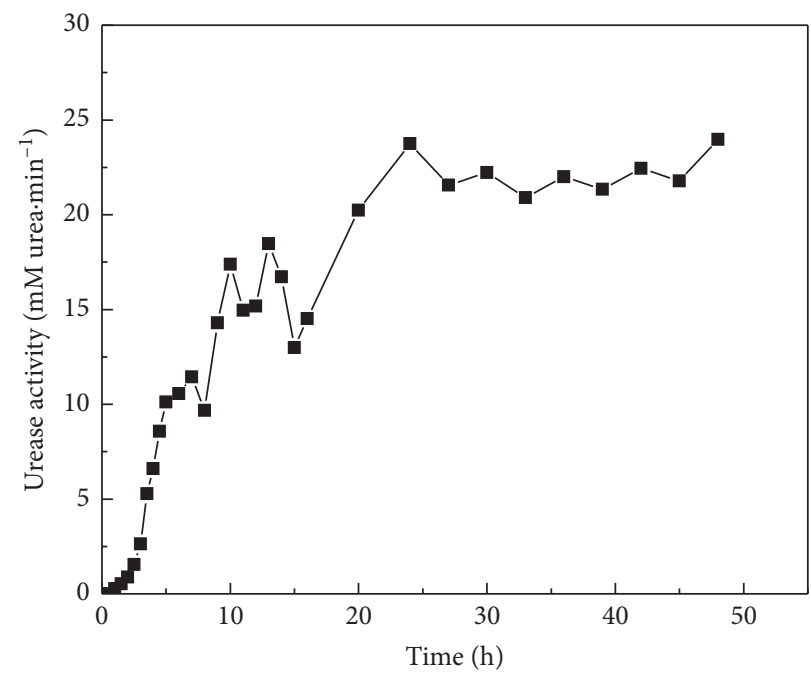

Figure 3: Variations in bacterial urease activity with time.

consistent in the process of bacterial culture, showing a slow growth within $0-3 \mathrm{~h}$ and a rapid growth within $3-24 \mathrm{~h}$. The urease activity reaches the maximum value after 24 hours of culture. In the present experiment, bacteria solution cultured for $24 \mathrm{~h}$ is selected for the experiment to ensure the consistency of bacterial concentration and urease activity.

2.2. Specimen Preparation. In order to prefabricate cracks with different roughness, polymethyl methacrylate (PMMA) material is applied to make rock-like specimens. Based on Barton's theory [39] of crack roughness, four cylindrical rock-like specimens containing prefabricated cracks with different joint roughness coefficients (JRCs) are manufactured using numerically controlled (NC) machine 
tools, as shown in Figure 4. The cylindrical specimens are $50 \mathrm{~mm}$ in diameter and $100 \mathrm{~mm}$ in height. A small pad with a certain width is used to splice the specimens between the crack surfaces to form a crack with a required width. A groove with width of $3 \mathrm{~mm}$ and depth of $3 \mathrm{~mm}$ is made at the top of the crack on each specimen to place burette tubes, as shown in Figure 4(a). Furthermore, glass glue is used to seal the two sides of the pre-existing crack, and a single layer of gauze is placed at the bottom of the preexisting crack to simulate the crack tip.

2.3. Experimental Setup. As shown in Figures 5(a) and 5(b), a bracket for placing samples during the titration process was designed and manufactured. The bracket was composed of two plastic plates which were joined together. The connecting part was designed to be rotatable so that the effects of inclination angle on fracture permeability can be investigated. A bracket was set behind the plate to adjust the angle between the two plates. A groove for collecting waste liquid was installed under the bracket and a catheter was inserted to facilitate the discharge of waste liquid.

The permeability coefficient of fractures is tested using the variable head method [30]. As shown in Figure 5(c), the bacteria-filled specimens were put into the Buchner funnel and sealed with glass glue and waterproof tape. A vertical and scaled glass tube was used to connect closely with the bottom of the funnel through a rubber tube, and water was added to the rubber hose to a specified height to maintain the water column. When the upper surface of the fracture overflows, the initial head height $h 1$ was recorded, and the time when the head dropped to a certain height $h 2$ was recorded. The initial head height was changed, and repeated measurements were made.

2.4. Injection Strategy. The filling fluid is composed of bacterial solution and $\mathrm{CaCl}_{2}$ solution. According to Harkes's work [26], the concentration of $\mathrm{CaCl}_{2}$ solution is $0.8 \mathrm{~mol} / \mathrm{L}$ in this study. The two solutions are packed in two containers, respectively. The titrator tubes are placed in the groove above the fracture. Then, bacteria solution and urea $+\mathrm{CaCl}_{2}$ solution are added into the pre-existing crack in the specimen through two titrator tubes at the same time and same injection rate. The biogrout flows under the action of gravity with the rate of $0.003 \mathrm{ml} / \mathrm{s}$. Each specimen is treated three times using the above method, $50 \mathrm{ml}$ of bacterial solution is added each round, and the specimens are placed for 12 hours after each treatment.

In the present experiment, the effects of bacterial concentration, crack inclination angle, crack roughness, and crack width on the filling effect of MICP are studied. The optical density (OD) is $0.5,1.0,1.5$, and 2.0. The JRC of the pre-existing cracks for each specimen is set to $6.7,10.8,14.5$, and 18.7, respectively. The crack opening is $0.5 \mathrm{~mm}, 1 \mathrm{~mm}$, $1.5 \mathrm{~mm}$, and $2 \mathrm{~mm}$, respectively. The inclination angle of cracks is set to $30^{\circ}, 45^{\circ}, 60^{\circ}$, and $75^{\circ}$, respectively. The experimental design is shown in Table 2.
2.5. Calcium Carbonate Content Test. The effluent from each filling process is collected, and the content of calcium ion in the effluent is measured by the titration method. The total amount of calcium ion in the solution is subtracted from the amount of calcium ion in the effluent to obtain the content of calcium carbonate in the cracks. Then, the content of calcium carbonate can be written as

$$
M_{c}=M_{t}-M_{s}
$$

in which $M_{c}$ is the content of calcium carbonate, $M_{t}$ represents the total amount of calcium ion in the solution, and $M_{s}$ denotes the amount of calcium ion in the effluent.

2.6. Permeability Analysis. According to the research of Mountassir et al. [35], calcium carbonate produced by the MICP process is granular and it can fill the fracture, so the relevant formula of the variable head test is used to calculate the fracture permeability in this study. Then, the permeability coefficient of the crack can be obtained as

$$
k=2.3 \frac{a L}{A \Delta t} \lg \left(\frac{H_{1}}{H_{2}}\right) \text {, }
$$

where $a$ is the cross-sectional area of rubber hose, $L$ represents the seepage diameter, i.e., the height of the sample, $t$ denotes the time interval, $H_{1}$ and $H_{2}$ are the initial head height and the termination head height, and $A$ is the crosssectional area of fracture.

\section{Result and Discussion}

After several MICP filling processes, it can be observed that the pre-existing cracks of the rock-like specimens are gradually filled with white calcium carbonate. However, with the change of external factors, the filling mode of calcium carbonate in the filling process and the final filling effect are different. The following sections are the analysis of the filling mode and filling effect of calcium carbonate under different factors, and the mechanism of its action is elaborated.

\subsection{Effect of Bacterial Concentration on Reduction Infiltration.} Figure 6(a) shows the filling process of calcium carbonate under different bacterial concentrations. It can be observed from the Figure 6(a) that the filling process of calcium carbonate changes significantly with the increase of bacterial concentration. During the filling process, the liquid was injected by the injection port and flows under the action of gravity, producing obvious white calcium carbonate precipitation on the flow path. With the increase of bacterial concentration, the precipitation diffusion rate of calcium carbonate increased, and the overall performance was that the filling mode of calcium carbonate gradually changed from the upward filling mode at the bottom of the fracture to the filling mode around the injection inlet, and the calcium carbonate distribution in the fracture was more even.

The variations of calcium carbonate content with different ODs and treatment times are plotted in Figure 6(b). According to Figures 6(a) and 6(b), with the increase of 


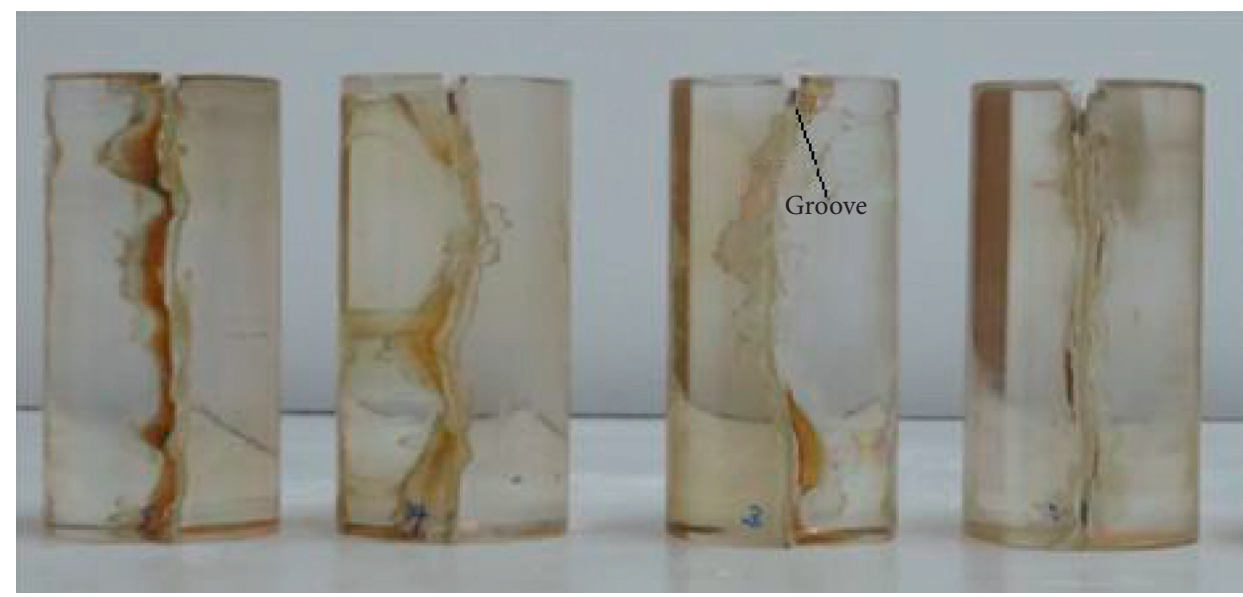

(a)

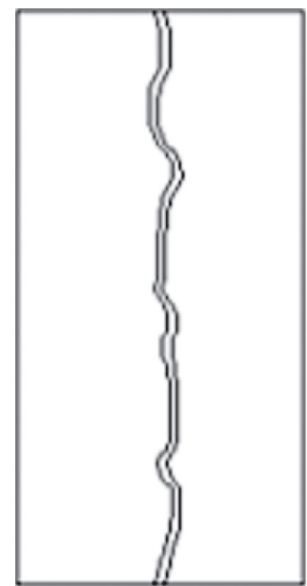

$\mathrm{JRC}=18.7$

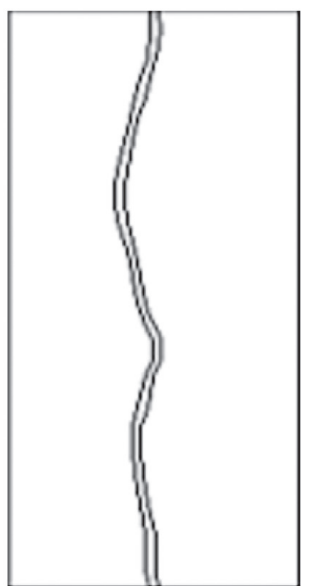

$\mathrm{JRC}=14.5$

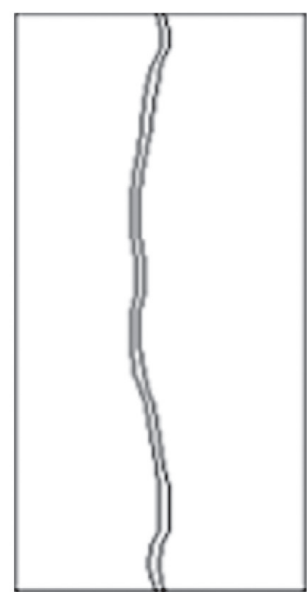

$\mathrm{JRC}=10.8$

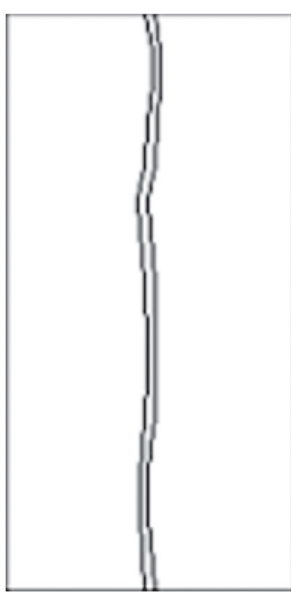

$\mathrm{JRC}=6.7$

(b)

FIGURE 4: Specimens with prefabricated cracks. (a) Rock-like specimens containing prefabricated cracks with different joint roughness coefficients. (b) Sketch of prefabricated cracks with different joint roughness coefficients.

filling times, the precipitation range of calcium carbonate generated near the injection port and in the flow path increases, and the yield of calcium carbonate increases during each filling process. This is because the continuous filling of calcium carbonate affects the subsequent slurry flow and increases the filling efficiency of calcium carbonate [32]. As shown Figure 6(b), in the first filling process, the yield of calcium carbonate increases from $35 \%$ to $65 \%$ with the increase of bacterial concentration. In the second filling round, the yield of calcium carbonate increases from $42 \%$ to $81 \%$. In the third filling round, the yield of calcium carbonate increased from $51 \%$ to $79 \%$. It can be observed from Figure 6(c) that the content of calcium carbonate in fractures increases from $42 \%$ to $75 \%$ with the increase of bacterial concentration after the filling process, which indicated that bacterial concentration had a great influence on the yield of calcium carbonate in the filling process. The fracture permeability decreases with the increase of bacterial concentration, from $1.475 \times 10^{-2} \mathrm{~cm} / \mathrm{s}$ to $3.1 \times 10^{-3} \mathrm{~cm} / \mathrm{s}$, which is caused by the increase of calcium carbonate content in the fracture and the more uniform distribution.

According to the second part of the study, the variation trend of bacterial concentration and urease activity with culturing is consistent, which affects the decomposition rate of urea in solution. Under the same flow conditions, the increase of bacterial concentration leads to the acceleration of urea decomposition and increases the precipitation rate of calcium carbonate, making it easier to precipitate in the injection port and flow path. Figures 6(b) and 6(c) also show that the increase of bacterial concentration will enhance the precipitation rate of calcium carbonate. In addition, it can be noted that no matter how the concentration of bacteria changes, white calcium carbonate will be produced at the bottom of the fracture, which is different from the results of study in sand [23]. However, MICP grouting slurry has low flow viscosity and fast filling speed. When it is applied to sandy soil, excessive bacterial concentration will make a large amount of calcium carbonate rapidly produced near the injection port and lead to the failure of subsequent grout 


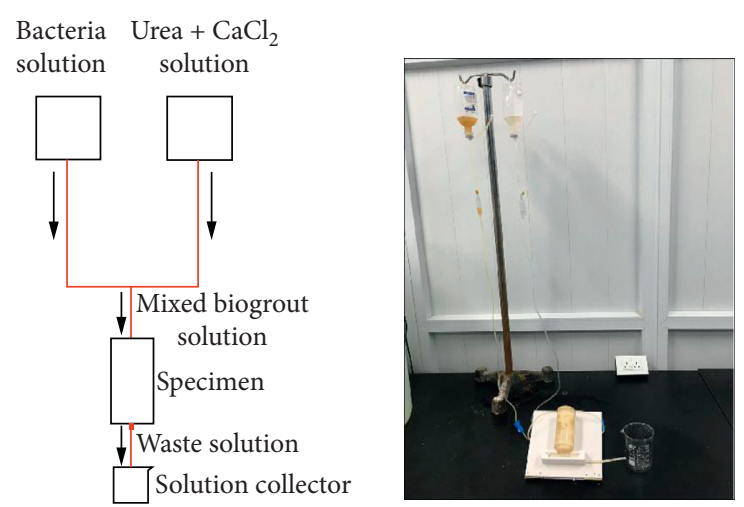

(a)
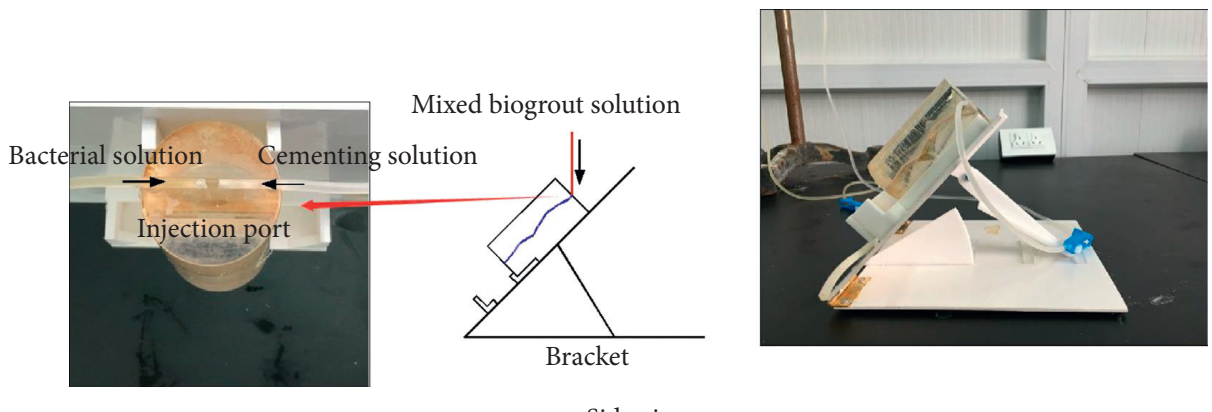

Side view

(b)

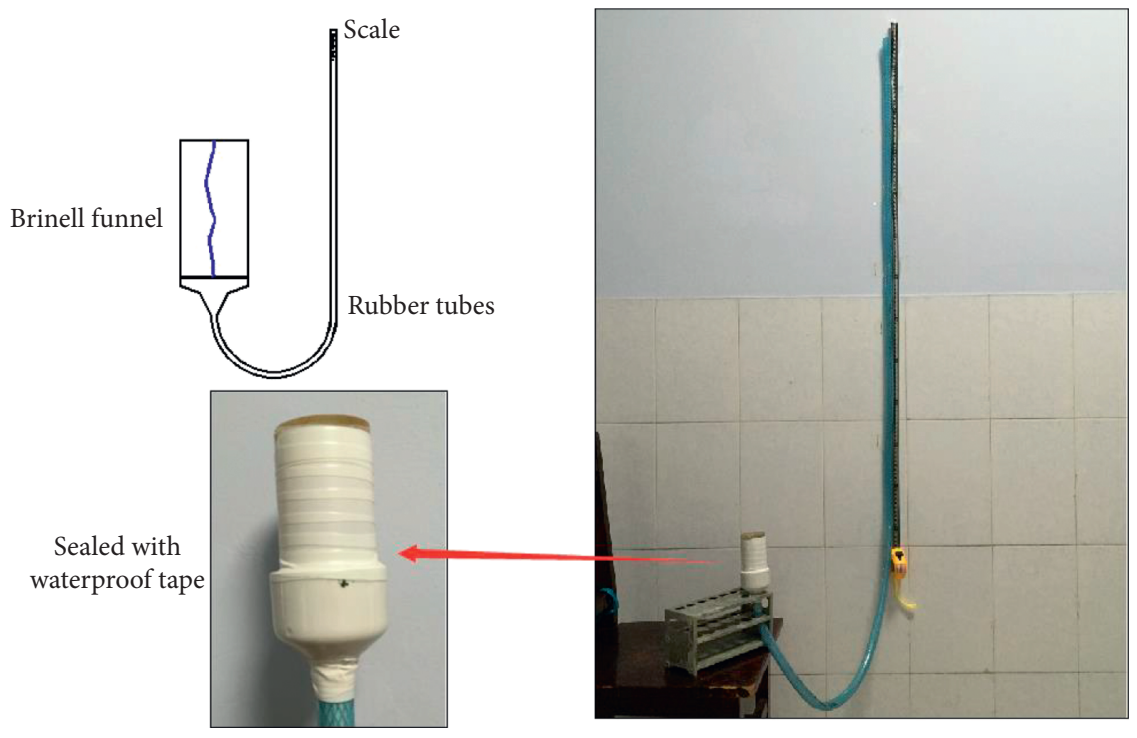

(c)

Figure 5: Experimental setup. (a) Schematic of biogrout solution flow arrangement. (b) Side view of experimental bracket. (c) The measuring equipment of permeability coefficient.

to enter. The fracture farther away from the injection port tended to decrease the calcium carbonate content. However, it can be obtained from Figure 6 that under certain fracture conditions, the increase of bacterial concentration has a promoting effect on the filling effect. This situation is caused by the slurry retention ability of the fracture, and it also proves that the application of MICP technology to fracture rock mass has practical engineering significance.
3.2. Effect of Crack Inclination Angle on Reduction Infiltration. In the present experiment, the biogrout solution was produced under the action of $1 \mathrm{~g}$ gravity, and the slurry flow velocity also changed when the crack inclination angle changed. Figure $7(\mathrm{a})$ shows the filling process of calcium carbonate under different crack inclination angles. It can be observed from Figure 7 (a) that the filling mode of calcium carbonate changes with the increase of fracture inclination 
TABle 2: Experimental design.

\begin{tabular}{lcccc}
\hline Number & JRC & Crack inclination angle $\left(^{\circ}\right)$ & OD & Crack opening $(\mathrm{mm})$ \\
\hline 3 & 14.5 & 45 & 0.5 & 1.5 \\
3 & 14.5 & 45 & 1 & 1.5 \\
3 & 14.5 & 45 & 1.5 & 1.5 \\
3 & 14.5 & 45 & 2 & 1.5 \\
\hline 3 & 14.5 & 30 & 2 & 1.5 \\
3 & 14.5 & 60 & 2 & 1.5 \\
3 & 14.5 & 75 & 2 & 1.5 \\
\hline 1 & 6.7 & 45 & 2 & 1.5 \\
2 & 10.8 & 45 & 2 & 1.5 \\
4 & 18.7 & 45 & 2 & 1.5 \\
\hline 3 & 14.5 & 45 & 2 & 0.5 \\
3 & 14.5 & 45 & 2 & 1 \\
3 & 14.5 & 45 & 2 & 2 \\
\hline
\end{tabular}

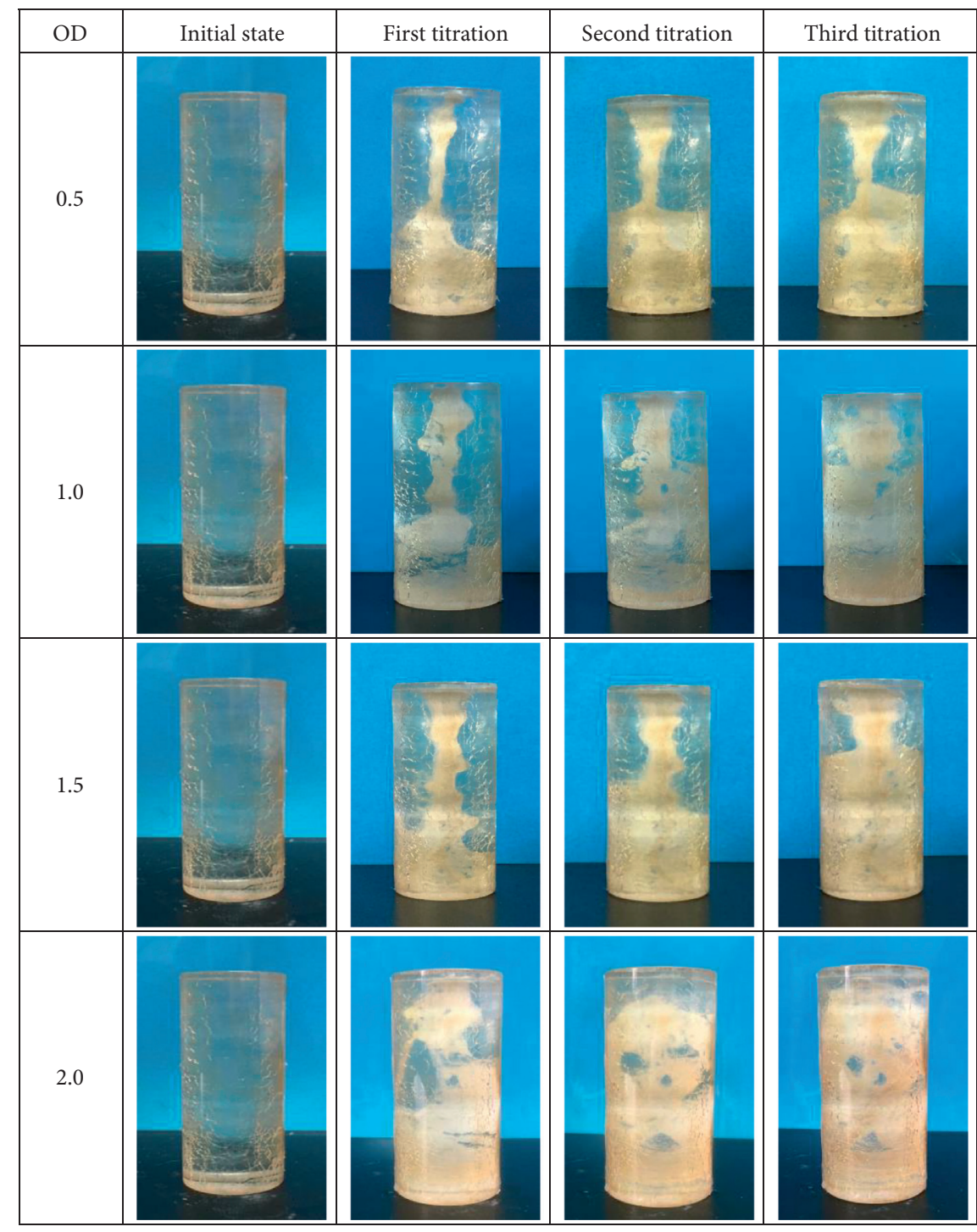

(a)

Figure 6: Continued. 


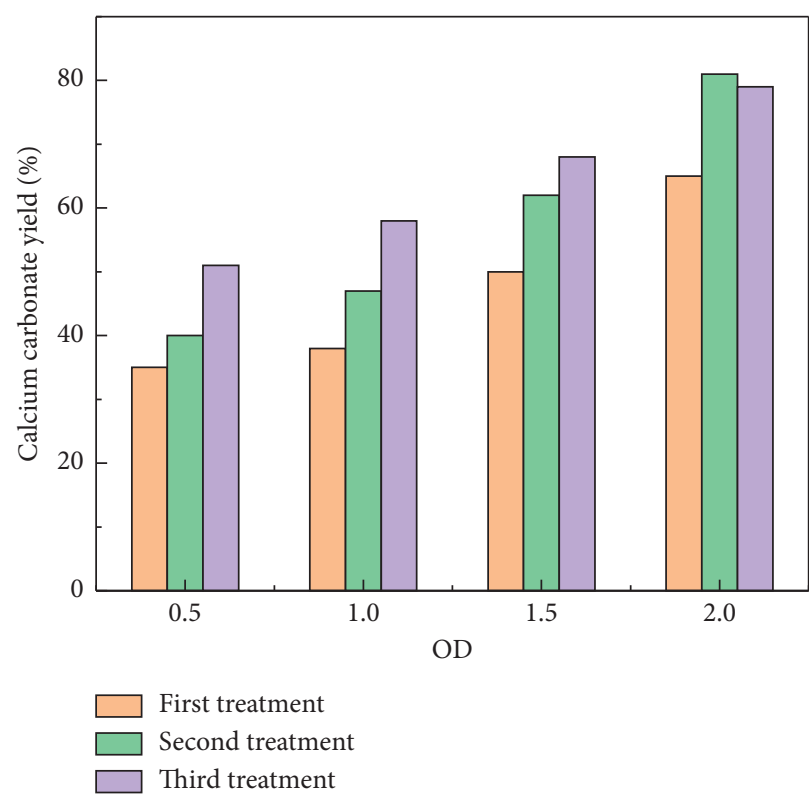

(b)

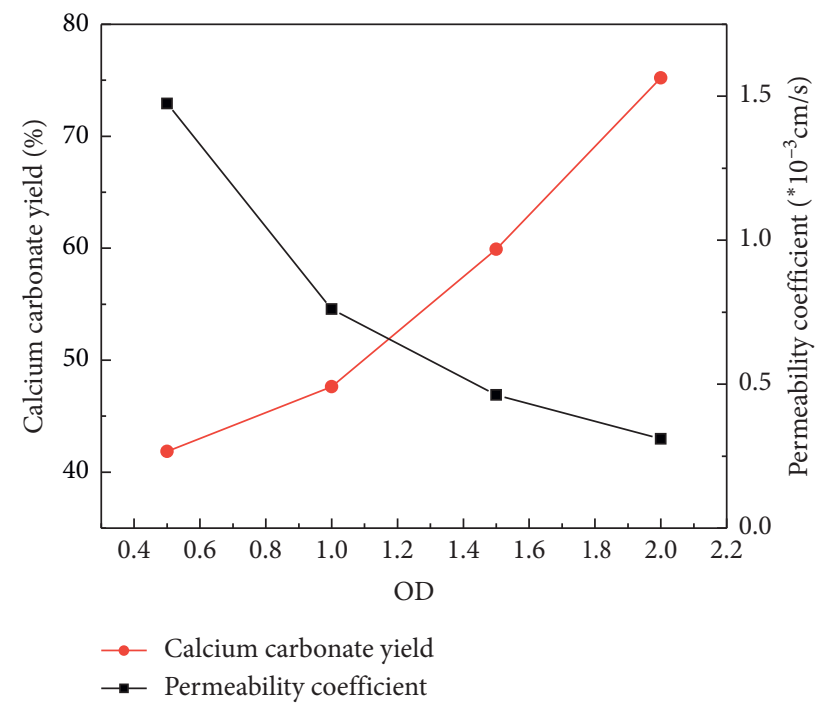

(c)

Figure 6: Filling effects of calcium carbonate with different bacterial concentrations. (a) Calcium carbonate filling process. (b) Change of calcium carbonate content. (c) Change of fracture permeability.

angle. When the crack inclination angle is $30^{\circ}$, a large amount of calcium carbonate is produced near the injection port and on the flow path during the first filling process. With the increase of the crack dip angle, it is found that the calcium carbonate produced in the injection port and the flow path is significantly reduced after the first filling process. This indicates that the liquid flow rate has an effect on the precipitation of calcium carbonate [35]. When the slurry flow speed is slow, the deposition rate of calcium carbonate increases, and it is easy to precipitate near the injection port and on the flow path. At the end of the three filling processes, the filling effect of calcium carbonate is different in the fractures. When the inclination angle is $30^{\circ}$, the middle part of the fractures is not filled; when the inclination angles are $45^{\circ}$ and $60^{\circ}$, the distribution of calcium carbonate is uniform; when the inclination angle is $75^{\circ}$, the upper part of the fractures is not filled.

It can be obtained from Figure 7(b) that during the first filling process, the yield of calcium carbonate decreases with the increase of fracture inclination angle, from $71.7 \%$ to $50.2 \%$. During the second filling process, the change trend of calcium carbonate yield changes, and the yield of calcium carbonate increases first and then decreases. The yield of calcium carbonate reaches its maximum value $(81 \%)$ when the fracture inclination angle is set to $45^{\circ}$. During the third filling process, the yield of calcium carbonate increases first and then decreases. When the dip angle is $30^{\circ}$, the minimum yield of calcium carbonate is about $36 \%$, and the maximum yield of fracture is $79 \%$ when the dip angles are $45^{\circ}$ and $60^{\circ}$. The reason is that too small fracture dip will cause calcium carbonate to deposit around the injection port, which will affect the entrance of the subsequent slurry and lead to a decrease in the yield of calcium carbonate. It can also be found from Figure 7(c) that after the completion of the three filling processes, with the increase of the fracture inclination angle, the total yield of calcium carbonate first increases and then decreases. As shown in Figure 7(c), with the increase of fracture inclination angle, the permeability of the fracture increases from $2.106 \times 10^{-3} \mathrm{~cm} / \mathrm{s}$ to $8.66 \times 10^{-3} \mathrm{~cm} / \mathrm{s}$. The overall performance is that the more the calcium carbonate content in the fracture, the lower the permeability coefficient. It is worth noting that when the dip angle of the fracture is $30^{\circ}$, although the content of calcium carbonate in the fracture is very low, the permeability of the fracture is the lowest. According to the experimental phenomenon and the research results of $\mathrm{Wu}$ et al. [37], it can be concluded that when the inclination angle is small, the slurry flow velocity slows down and a dense calcium carbonate layer is generated around the injection port, which greatly reduces the permeability of the fracture. It can be seen from the above analysis that when the MICP technology is used to prevent seepage in fractures, it greatly depends on the content of calcium carbonate in the fractures. Therefore, the key of the MICP technology is whether the calcium carbonate in the fractures can form a dense water barrier.

\subsection{Effect of Crack Roughness on Reduction Infiltration.} Figure 8(a) shows the change of filling mode of calcium carbonate in pre-existing cracks with different crack roughness. It is found from Figure 8(a) that with the increase of crack roughness, the filling range of calcium carbonate increases in the flow path. The filling mode of calcium carbonate generally changes from filling upward from the bottom of the fracture to diffusing around the injection port and the flow path. After the grouting process, it can be 


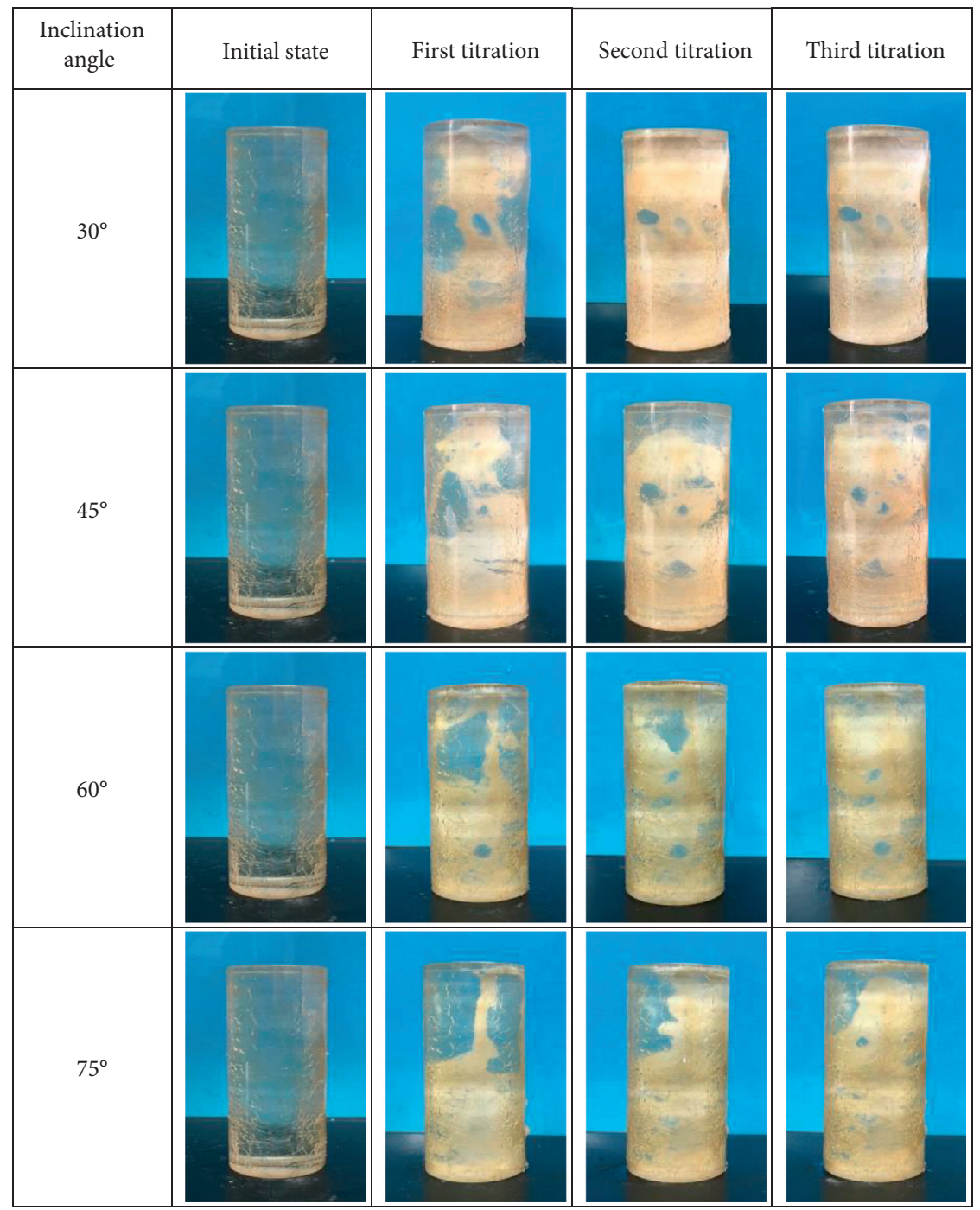

(a)

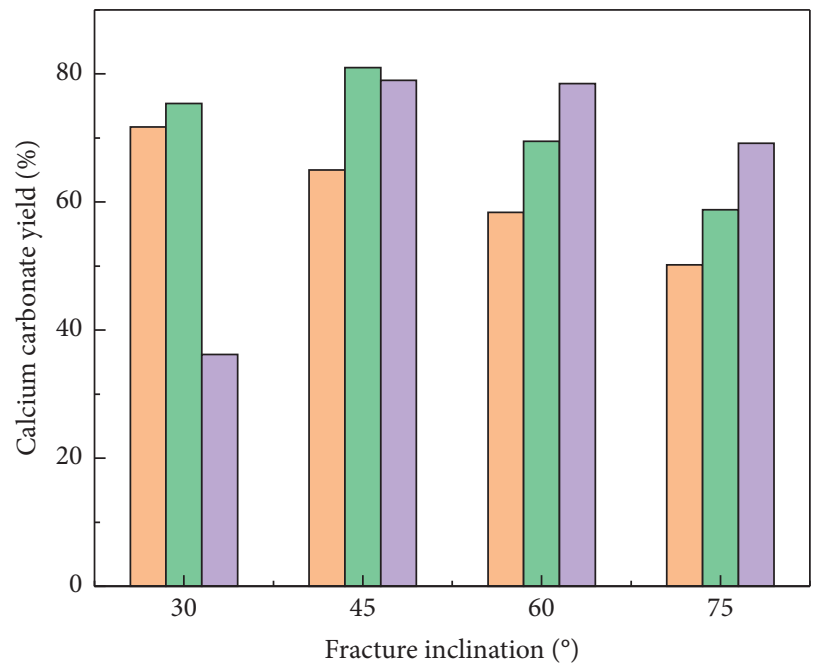

First treatment

Second treatment Third treatment

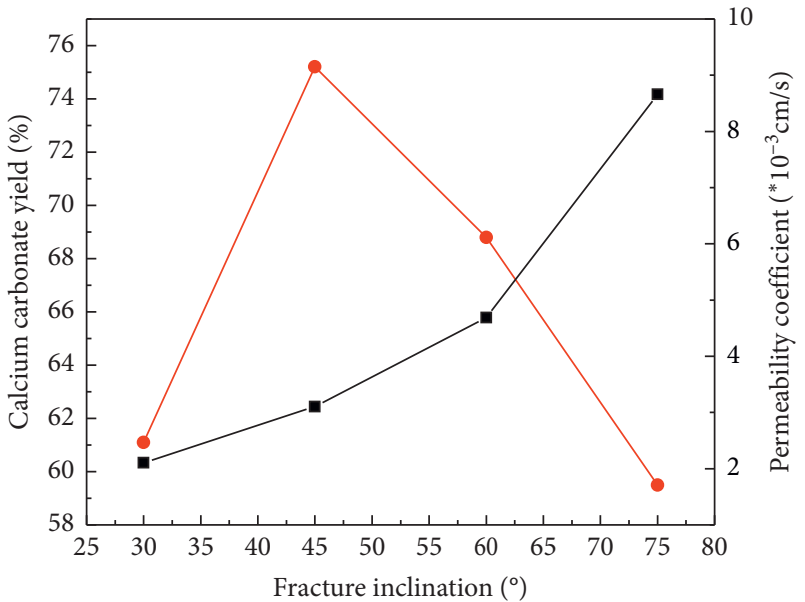

- - Calcium carbonate yield

$\rightarrow$ Permeability coefficient

(b)

(c)

FiguRE 7: Filling effect of calcium carbonate with different fracture inclination angles. (a) Calcium carbonate filling process. (b) Change of calcium carbonate content. (c) Change of fracture permeability. 


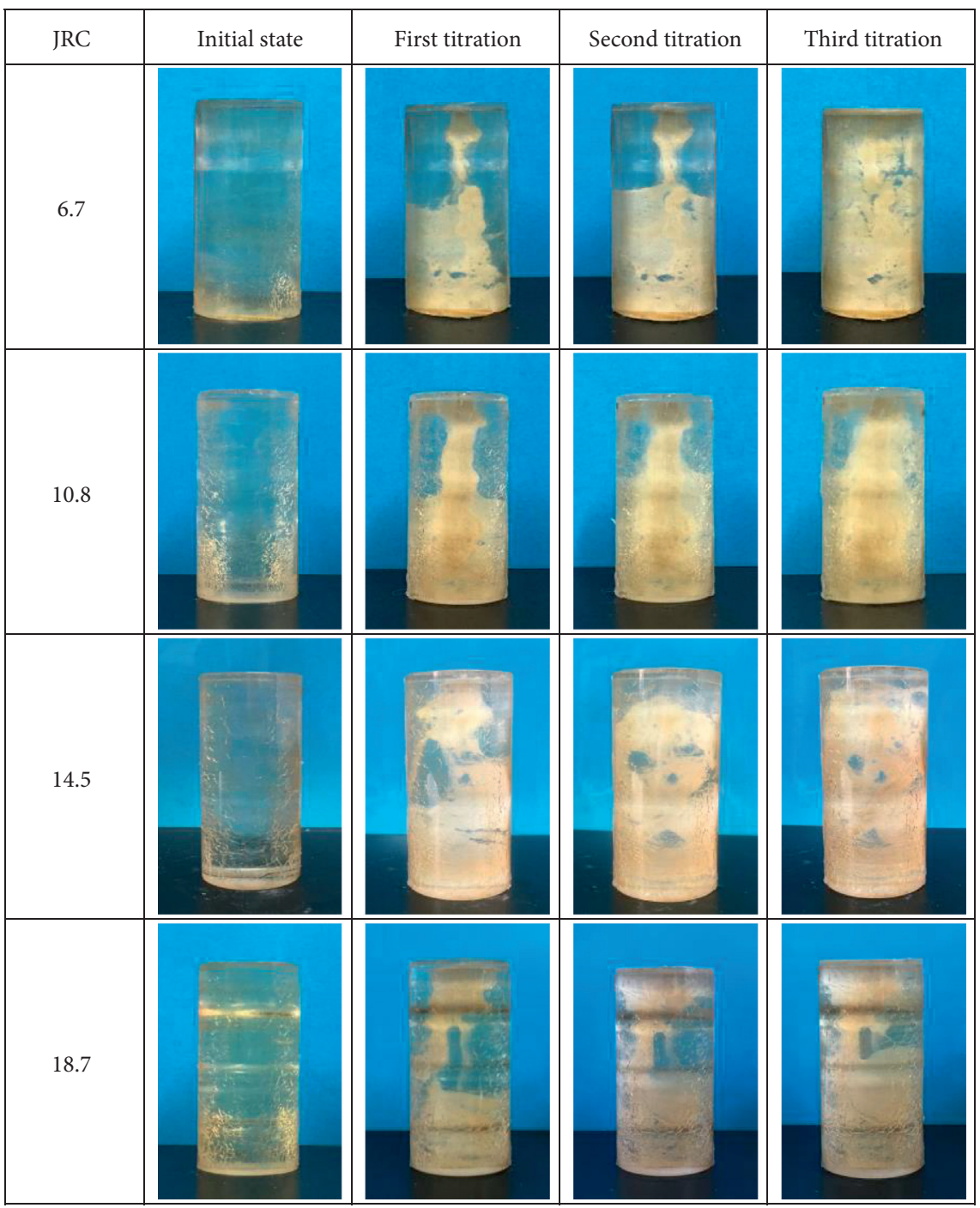

(a)
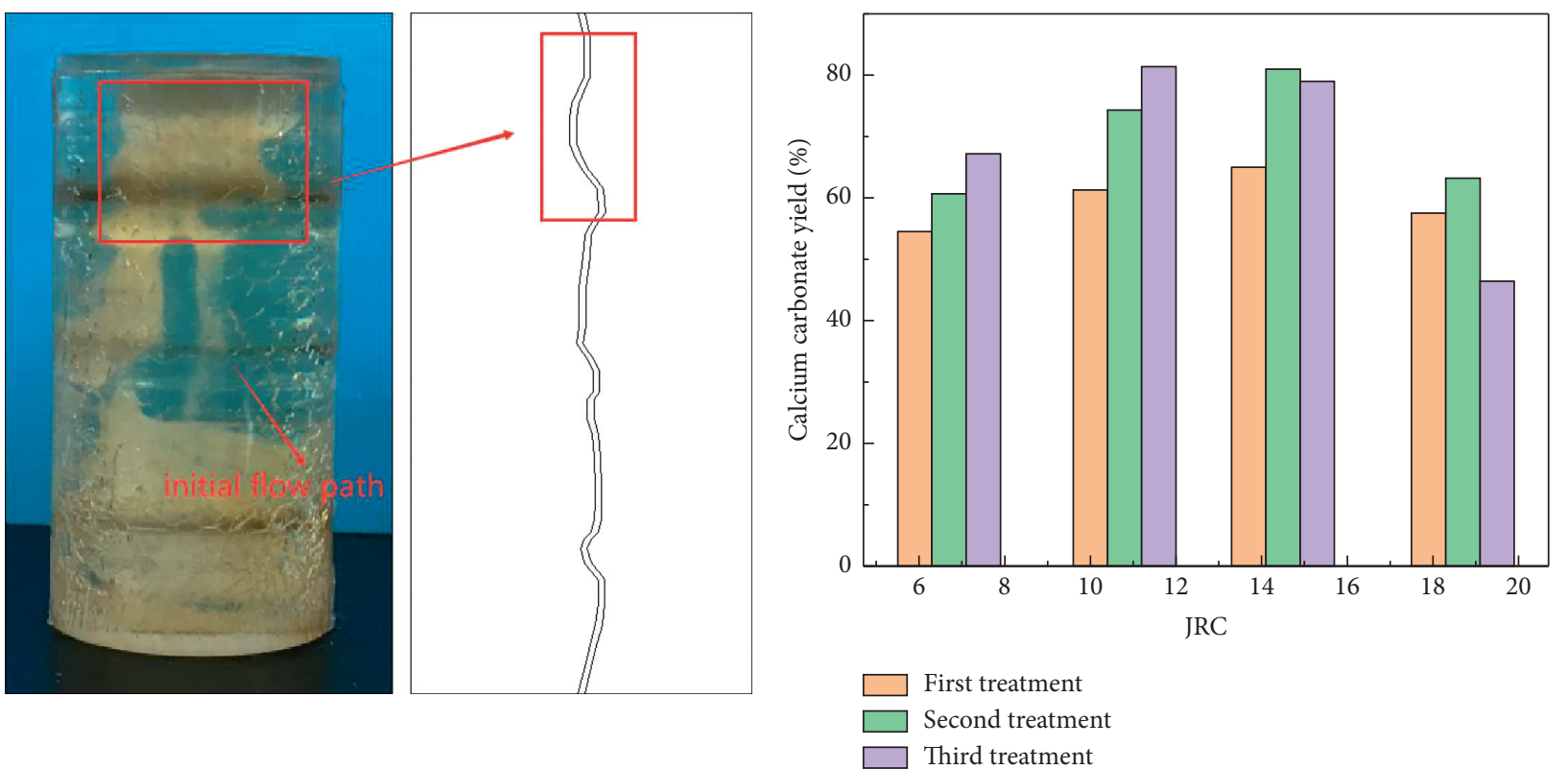

(b)

Figure 8: Continued. 


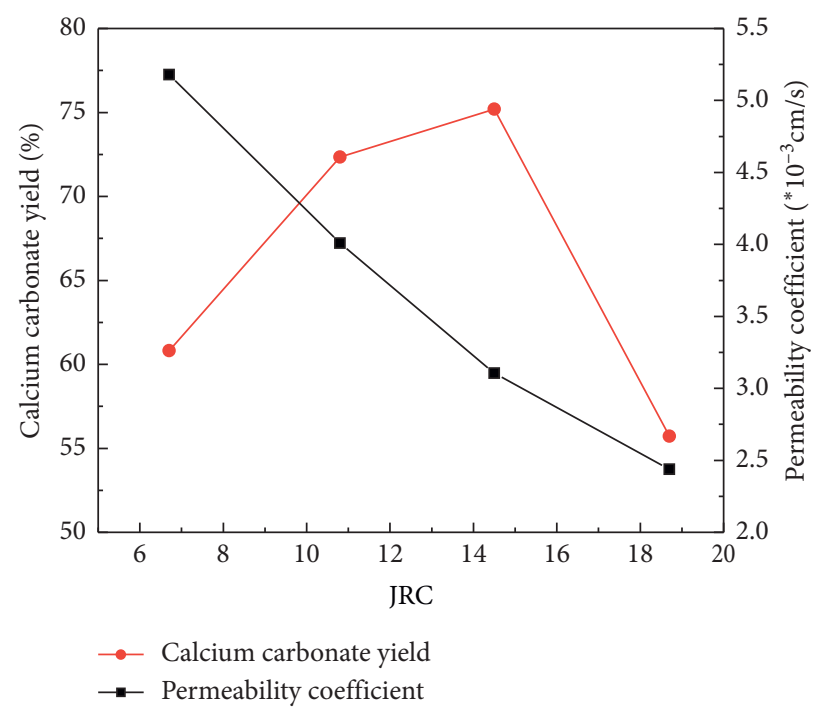

(d)

FIGURE 8: Filling effect of calcium carbonate with different fracture roughness. (a) Calcium carbonate filling process. (b) Specimen after first filling process $(\mathrm{JRC}=18.7)$. (c) Change of calcium carbonate content. (d) Change of fracture permeability.

obtained that when the fracture roughness is small $(\mathrm{JRC}=6.7, \mathrm{JRC}=10.8)$, a small part of the injection port is not filled, while when JRC $=18.7$, a large part of the middle part of the fracture is not filled.

According to the research of Cuthbert et al. [32] and Minto et al. [20], calcium carbonate is more easily able to precipitate in the parts with large crevice fluctuations. Figure 8 (b) shows the specimen with the JRC $=18.7$ after the first filling process, and it can be seen from Figure 8 (b) that calcium carbonate deposits the most in the fracture where the fracture fluctuation is the largest. Due to the precipitation of calcium carbonate, the subsequent slurry flow is restricted, and the slurry flow path is changed. Figure 8(c) shows the content of calcium carbonate in the fracture during the filling process. In the first filling process, the yield of calcium carbonate is the lowest $(54.5 \%)$ when the JRC value of the fracture is 6.7, and it is the highest (65\%) when the JRC value of the fracture surface is 14.5. During the second filling process, the yield of calcium carbonate is the smallest $(60.7 \%)$ when the JRC value of the fracture surface is 6.7 , and the yield of calcium carbonate reaches largest (81\%) when the JRC value of the fracture surface is 14.5 . In the third filling process, the yield of calcium carbonate is the smallest (46.4\%) when the fracture JRC value is 18.7 , and it is the largest $(81.4 \%)$ when the fracture JRC value is 10.8 . This indicates that the increase of crack roughness is conducive to the precipitation of calcium carbonate, but when the fracture roughness is too large, the precipitation of calcium carbonate in the early stage will restrict the subsequent slurry injection and lead to the decrease of the yield of calcium carbonate.

Figure $8(d)$ shows the change of permeability of the fracture with different JRCs. The permeability coefficient of the fracture decreases with the increase of the roughness of the fracture, which is negatively correlated with the content of calcium carbonate in the fracture. However, in the fracture with $\mathrm{JRC}=18.7$, the content of calcium carbonate is the lowest and the permeability coefficient is the lowest. It means that calcium carbonate forms dense calcium carbonate precipitation in the part with the biggest fluctuation of the fracture, which reduces the permeability of the fracture.

3.4. Effect of Crack Opening on Reduction Infiltration. Figure 9(a) shows the filling process of calcium carbonate in the pre-existing cracks under different aperture conditions. It can be seen from Figure 9(a) that with the increase of aperture, the precipitation of calcium carbonate around the injection port decreases, while the distribution of calcium carbonate at the bottom of the fractures increases. During the first filling process, the filling velocity of calcium carbonate decreases with the increase of crack opening. According to the cubic law, the reduction of crack opening will reduce the water passing capacity of the fracture and accelerate the precipitation of calcium carbonate. At the same time, small crack opening can be filled with calcium carbonate more quickly, which will restrict the subsequent grouting process and accelerate the precipitation of calcium carbonate. After the grouting process, the middle part of the fracture with an aperture of $0.5 \mathrm{~mm}$ is not filled. With the increase of the crack opening, the filling effect is improved. When the crack opening is $2 \mathrm{~mm}$, the upper part of the fracture cannot be filled.

The changes of calcium carbonate content in fractures with different fracture aperture in the filling processes are illustrated in Figure 9(b). During the first filling process, the yield of calcium carbonate in the fracture decreases from $73.4 \%$ to $48.7 \%$ as the aperture of the fracture increases. In the second filling process, the yield of calcium carbonate 


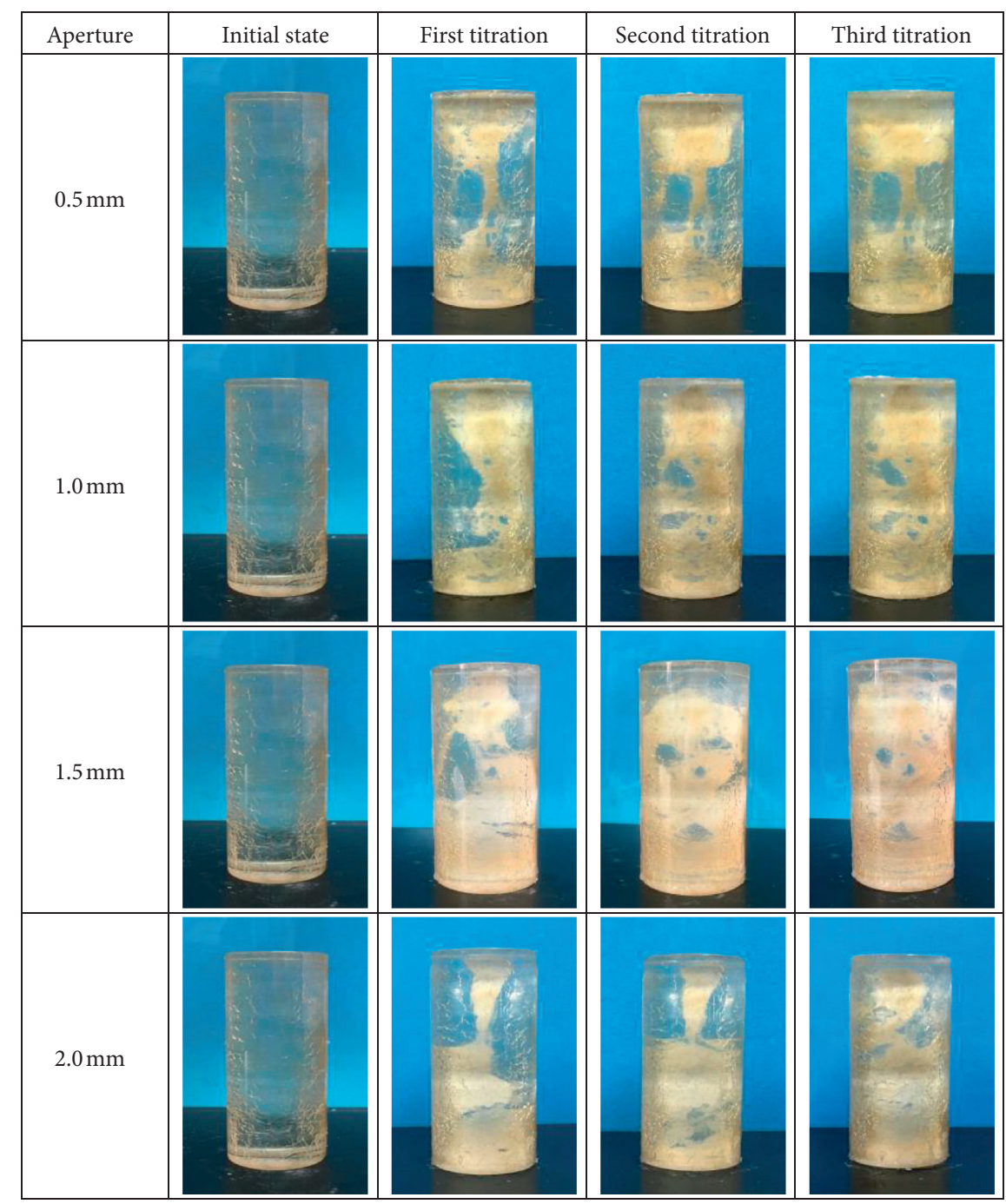

(a)

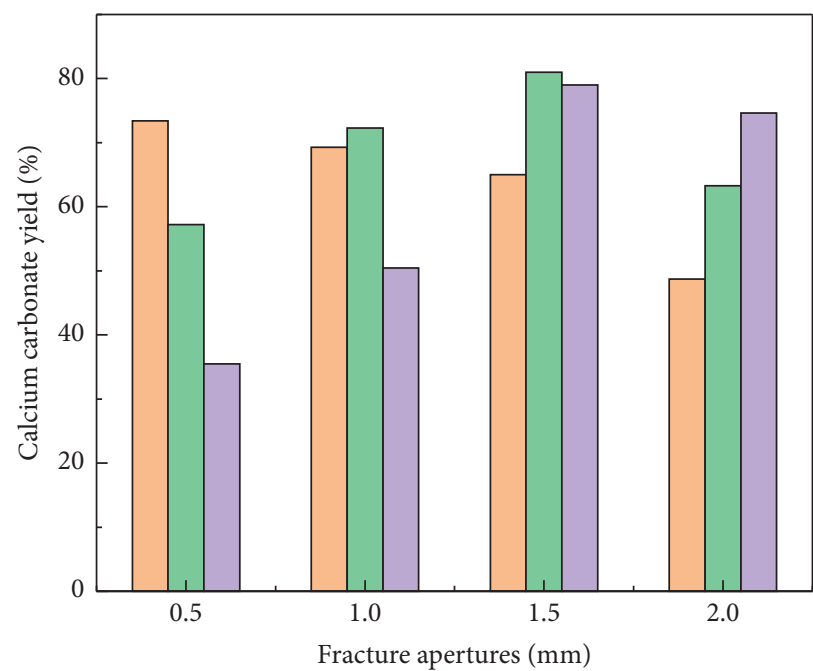

First treatment

Second treatment

Third treatment

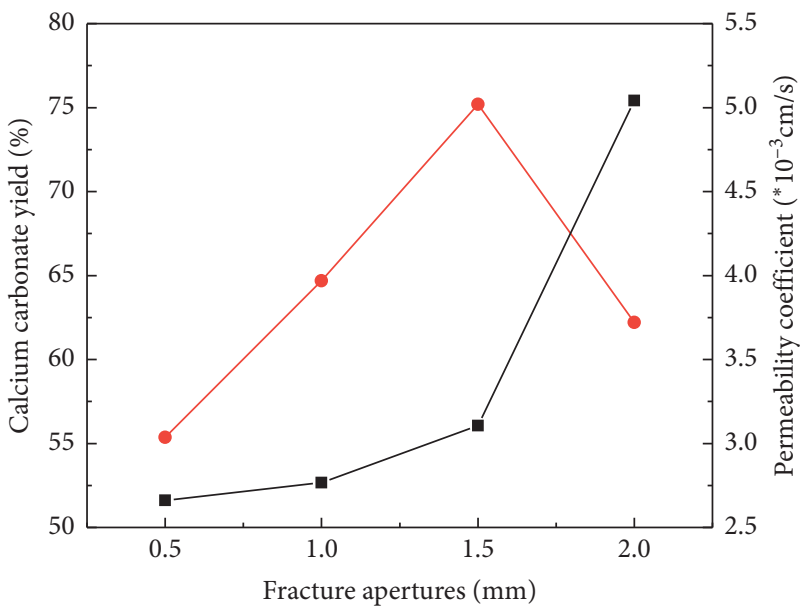

$\rightarrow$ Calcium carbonate yield

$\rightarrow$ Permeability coefficient

FIGURE 9: Filling effect of calcium carbonate with different fracture apertures. (a) Calcium carbonate filling process. (b) Change of calcium carbonate content. (c) Change of fracture permeability. 


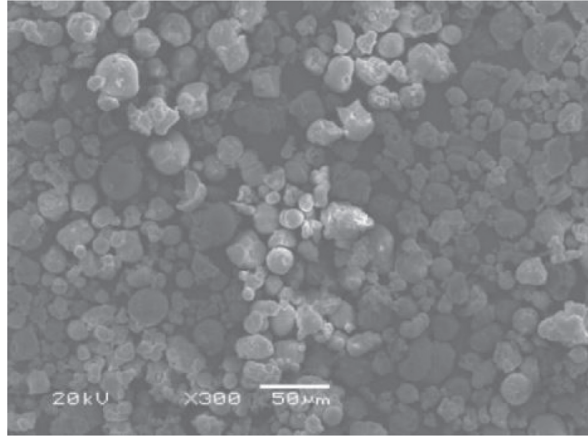

(a)

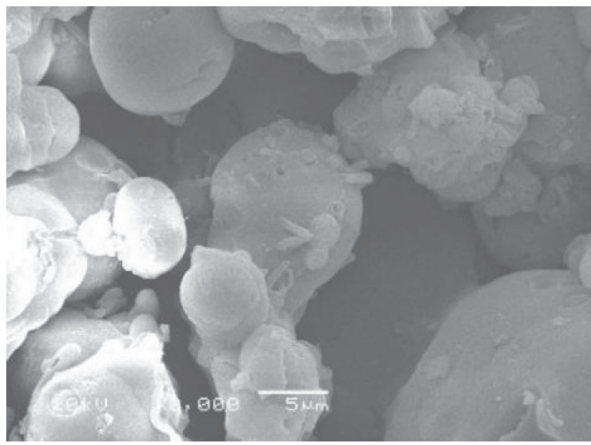

(c)

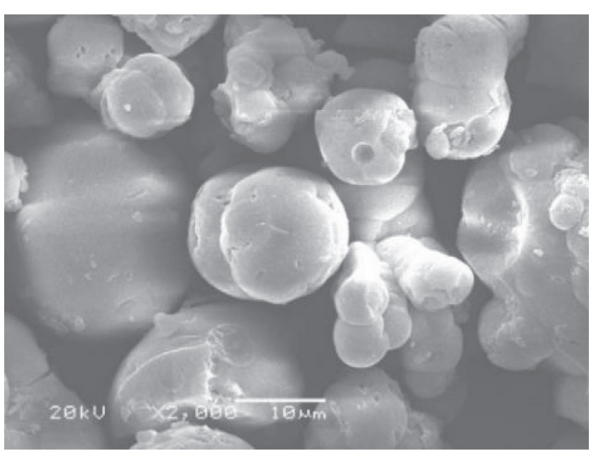

(b)

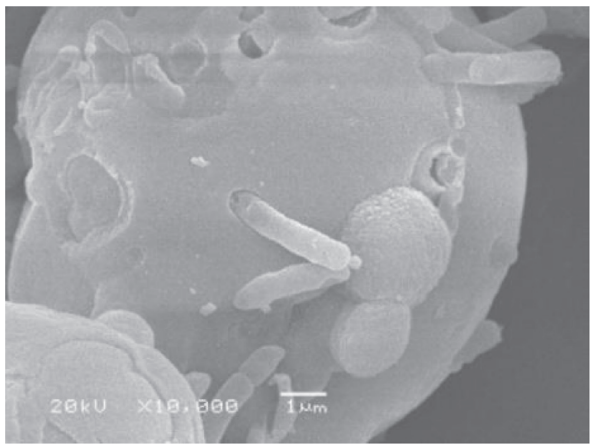

(d)

FIgURE 10: Microscopic morphology of calcium carbonate produced by MICP.

increases first and then decreases. The yield of calcium carbonate reaches the smallest (57.2\%) when the crack opening is $0.5 \mathrm{~mm}$, and it is the largest (81\%) when the crack opening is $1.5 \mathrm{~mm}$. During the third filling process, the yield of calcium carbonate is the smallest $(35.5 \%)$ when the crack opening is set to $0.5 \mathrm{~mm}$, and the yield of calcium carbonate reaches the largest (79\%) when the crack opening is $1.5 \mathrm{~mm}$. This indicates that small crack opening $(0.5 \mathrm{~mm}, 1.0 \mathrm{~mm})$ is conducive to the precipitation of calcium carbonate, but the precipitation of calcium carbonate near the injection port will hinder the subsequent grouting process and reduce the subsequent grouting efficiency. The large crack opening $(1.5 \mathrm{~mm}, 2 \mathrm{~mm})$ is not conducive to the precipitation of calcium carbonate in the early stage of filling, but in the subsequent grouting process, the precipitation of calcium carbonate at the bottom of the fracture will reduce the flow of slurry and improve the precipitation efficiency of calcium carbonate. Moreover, it can be found from Figure 9(c) that with the increase of crack opening, the permeability coefficient of the fracture increases after filling processes. On the one hand, the smaller crack opening leads to the smaller water passing capacity. On the other hand, the smaller crack opening is more easily blocked by calcium carbonate.

\subsection{The Microscopic Morphology of Calcium Carbonate.} Figure 10 shows the microstructure of calcium carbonate with different observation scales produced by MICP. It can be obtained from Figures 10(a)-10(d) that calcium carbonate generated by the MICP process is granular, with a diameter of about $20 \mu \mathrm{m}$. The particles are formed in the form of accumulation and bonding. As shown in Figures $10(\mathrm{c})$ and $10(\mathrm{~d})$, it is found that the bacteria are wrapped inside the calcium carbonate particles, which are consistent with the existing research conclusion $[24,40]$.

According to Kohnhauser's work [41], the MICP process is the production of urease by Sporosarcina pasteurii in the metabolic process, and the urease acts as a catalyst promoting the decomposition of urea in the environment (the decomposition rate is increased by 104 times). Since bacteria have negative charges themselves, calcium ions in the solution will adhere to the surface of bacteria, and bacteria provide crystal nuclei for the formation of calcium carbonate, which is conducive to the formation of precipitation [24]. In the MICP process, bacteria are mainly used to produce urease and to provide crystal nuclei for calcium carbonate precipitation. Therefore, Sporosarcina pasteurii has two main roles in the process of MICP: one is to provide urease and accelerate the decomposition of urea and the other is to provide the crystal nucleus for the formation of calcium carbonate and accelerate the precipitation of calcium carbonate.

\section{Conclusion}

In this study, the process of filling cracks with MICP is investigated. The effects of four external factors such as bacterial concentration, fracture inclination angle, crack roughness, and fracture aperture on the filling effect are studied. The results showed that calcium carbonate precipitation can be formed when bacteria and cementing fluid are injected into the cracks, which can seal the cracks and 
reduce the permeability of the cracks. The conclusions are drawn as follows:

(1) The content of calcium carbonate in cracks increases with the increase of bacterial concentration, and it increases first and then decreases with the increase of inclination angle, roughness, and opening of cracks, respectively.

(2) The filled crack permeability increases with the increase of bacterial concentration and crack roughness, and it decreases with the increase of crack inclination angle and crack opening, respectively.

(3) The concentration of bacteria is mainly reflected in the hydrolysis rate of urea in the slurry. And the fracture morphology will affect the filling mode of calcium carbonate. Therefore, it is necessary to make appropriate plans according to the actual situation of the engineering site when the MICP technology is applied to practical engineering.

(4) It can be concluded that the MICP technology can reduce the permeability of fractured rock mass and has the potential to be applied in waterproofing measures of fractured rock engineering. In order to get better practicability of the technology in engineering, it is necessary to conduct in-depth research including large-scale cracks and different injection methods in the future.

\section{Data Availability}

The data used to support the findings of this study are included within the article.

\section{Conflicts of Interest}

The authors confirm that the received funding that has been mentioned did not lead to any conflicts of interest regarding the publication of this manuscript.

\section{Acknowledgments}

This study was supported by National Breeding Base of Technology and Innovation Platform for Automatic Monitoring of Geologic Hazards and Chongqing Engineering Research Center of Automatic Monitoring for Geological Hazards.

\section{References}

[1] X. P. Zhou, J. Bi, and Q. H. Qian, "Numerical simulation of crack growth and coalescence in rock-like materials containing multiple pre-existing flaws," Rock Mechanics and Rock Engineering, vol. 48, no. 3, pp. 1097-1114, 2015.

[2] X. P. Zhou, Y. X. Zhang, Q. L. Ha, and K. S. Zhu, "Micromechanical modelling of the complete stress-strain relationship for crack weakened rock subjected to compressive loading," Rock Mechanics and Rock Engineering, vol. 41, no. 5, pp. 747-769, 2008.

[3] J. Bi, X. P. Zhou, and Q. H. Qian, "The 3D numerical simulation for the propagation process of multiple pre-existing flaws in rock-like materials subjected to biaxial compressive loads," Rock Mechanics and Rock Engineering, vol. 49, no. 5, pp. 1611-1627, 2016.

[4] X. P. Zhou, J. Z. Zhang, and L. N. Y. Wong, "Experimental study on the growth, coalescence and wrapping behaviors of 3D cross-embedded flaws under uniaxial compression," Rock Mechanics and Rock Engineering, vol. 51, no. 5, pp. 1379-1400, 2018.

[5] Y. Wang, X. Zhou, X. Xu, and X. Xu, "Numerical simulation of propagation and coalescence of flaws in rock materials under compressive loads using the extended non-ordinary state-based peridynamics," Engineering Fracture Mechanics, vol. 163, pp. 248-273, 2016.

[6] J. Z. Zhang and X. P. Zhou, "Forecasting catastrophic rupture in brittle rocks using precursory AE time series," Journal of Geophysical Research: Solid Earth, vol. 125, no. 8, Article ID e2019JB019276, 2020.

[7] Z. Zhao and X. P. Zhou, "An integrated method for 3D reconstruction model of porous geomaterials through 2D CT images," Computers \& Geosciences, vol. 123, pp. 83-94, 2019.

[8] Z. Zhao and X.-P. Zhou, "Establishment of numerical cracking constitutive models using $3 \mathrm{D}$ reconstruction and X-ray CT images of geomaterials," International Journal of Mechanical Sciences, vol. 183, Article ID 105814, 2020.

[9] X. C. Huang and X. P. Zhou, "Probabilistic assessment for slope using the generalized Chebyshev inequalities," International Journal of Geomechanics, vol. 20, no. 4, Article ID 06020003, 2020.

[10] X. P. Zhou, X. C. Huang, P. F. Liu, and T. F. Li, “A probabilistic method to analyze collapse failure of shallow rectangular tunnels," Tunnelling and Underground Space Technology, vol. 82, pp. 9-19, 2018.

[11] X. P. Zhou, X. C. Huang, and X. F. Zhao, "Optimization of the critical slip surface of three-dimensional slope by using an improved genetic algorithm," International Journal of Geomechanics, vol. 20, no. 8, Article ID 04020120, 2020.

[12] X. P. Zhou, X. C. Huang, and J. X. Li, "Reliability assessment of tunnel based on $\mathrm{P}$-wave seismic velocity," International Journal of Geomechanics, vol. 18, no. 11, Article ID 06018030, 2018.

[13] Y. Shou and X. Zhou, "A coupled hydro-mechanical nonordinary state-based peridynamics for the fissured porous rocks," Engineering Analysis with Boundary Elements, vol. 123, pp. 133-146, 2021.

[14] P. Duffaut, "The traps behind the failure of Malpasset arch dam, France, in 1959," Journal of Rock Mechanics and Geotechnical Engineering, vol. 5, no. 5, pp. 335-341, 2013.

[15] C. R. J. Kilburn and D. N. Petley, "Forecasting giant, catastrophic slope collapse: lessons from Vajont, Northern Italy," Geomorphology, vol. 54, no. 1, pp. 21-32, 2003.

[16] N. D. Rose and O. Hungr, "Forecasting potential rock slope failure in open pit mines using the inverse-velocity method," International Journal of Rock Mechanics and Mining Sciences, vol. 44, no. 2, pp. 308-320, 2007.

[17] K. Q. He, W. C. Yu, and W. F. Jiang, "Analysis of groundwater inrush conditions and critical inspection parameters at the baixiangshan iron mine, China," Mine Water and the Environment, vol. 30, pp. 274-283, 2011.

[18] J. Chu, V. Ivanov, J. He, and M. Naeimi, "Development of microbial geotechnology in Singapore," in Proceedings of the Geo-Frontiers Congress 2011, pp. 070-4078, ASCE, Dallas, TX, USA, March 2011. 
[19] M. B. Ali, R. Saidur, and M. S. Hossain, "A review on emission analysis in cement industries," Renewable and Sustainable Energy Reviews, vol. 15, no. 5, pp. 2252-2261, 2011.

[20] J. M. Minto, E. Maclachlan, G. El Mountassir, and R. J. Lunn, "Rock fracture grouting with microbially induced carbonate precipitation," Water Resources Research, vol. 52, no. 11, pp. 8827-8844, 2016.

[21] V. Ivanov and J. Chu, "Applications of microorganisms to geotechnical engineering for bioclogging and biocementation of soil in situ," Reviews in Environmental Science and Biotechnology, vol. 7, no. 2, pp. 139-153, 2008.

[22] J. K. Mitchell and J. C. Santamarina, "Biological considerations in geotechnical engineering," Journal of Geotechnical and Geoenvironmental Engineering, vol. 131, no. 10, pp. 1222-1233, 2005.

[23] Q. Zhao, L. Li, C. Li, M. Li, F. Amini, and H. Zhang, "Factors affecting improvement of engineering properties of MICPtreated soil catalyzed by bacteria and urease," Journal of Materials in Civil Engineering, vol. 26, no. 12, Article ID 04014094, 2014.

[24] J. T. DeJong, M. B. Fritzges, and K. Nüsslein, "Microbially induced cementation to control sand response to undrained shear," Journal of Geotechnical and Geoenvironmental Engineering, vol. 132, no. 11, pp. 1381-1392, 2006.

[25] V. S. Whiffin, L. A. van Paassen, and M. P. Harkes, "Microbial carbonate precipitation as a soil improvement technique," Geomicrobiology Journal, vol. 24, no. 5, pp. 417-423, 2007.

[26] M. P. Harkes, L. A. van Paassen, J. L. Booster, V. S. Whiffin, and M. C. M. van Loosdrecht, "Fixation and distribution of bacterial activity in sand to induce carbonate precipitation for ground reinforcement," Ecological Engineering, vol. 36, no. 2, pp. 112-117, 2010.

[27] H. Yasuhara, K. Hayashi, and M. Okamura, "Evolution in mechanical and hydraulic properties of calcite-cemented sand mediated by biocatalyst," in Proceedings of the Geo-Frontiers Congress 2011, Dallas, TX, USA, March 2011.

[28] M. Burbank, T. Weaver, R. Lewis, T. Williams, B. Williams, and R. Crawford, "Geotechnical tests of sands following bioinduced calcite precipitation catalyzed by indigenous bacteria," Journal of Geotechnical and Geoenvironmental Engineering, vol. 139, no. 6, pp. 928-936, 2012.

[29] L. A. V. Paassen, R. Ghose, T. J. M. V. D. Linden, W. R. L. V. D. Star, and M. C. M. V. Loosdrecht, "Quantifying biomediated ground improvement by ureolysis: large-scale biogrout experiment," Journal of Geotechnical and Geoenvironmental Engineering, vol. 136, no. 12, pp. 1721-1728, 2010.

[30] D. Li, K. L. Tian, H. L. Zhang, Y. Y. Wu, K. Y. Nie, and S. C. Zhang, "Experimental investigation of solidifying desert aeolian sand using microbially induced calcite precipitation," Construction and Building Materials, vol. 172, pp. 251-262, 2018.

[31] F. G. Ferris, L. G. Stehmeier, A. Kantzas, and F. M. Mourits, "Bacteriogenic mineral plugging," Journal of Canadian Petroleum Technology, vol. 35, no. 8, pp. 56-61, 1996.

[32] M. O. Cuthbert, L. A. McMillan, S. Handley-Sidhu, M. S. Riley, D. J. Tobler, and V. R. Phoenix, "A field and modeling study of fractured rock permeability reduction using microbially induced calcite precipitation," Environmental Science and Technology, vol. 47, no. 23, pp. 1363713643, 2013.

[33] A. J. Phillips, E. Lauchnor, J. Eldring et al., "Potential $\mathrm{CO}_{2}$ leakage reduction through biofilm-induced calcium carbonate precipitation," Environmental Science and Technology, vol. 47, no. 1, pp. 142-149, 2013.

[34] N. A. Bucci, E. Ghazanfari, and H. J. Lu, "Microbially-induced calcite precipitation for sealing rock fractures," in Proceedings of the Geo-Chicago 2016, Chicago, IL, USA, August 2016.

[35] G. E. Mountassir, R. J. Lunn, H. Moir, and E. MacLachlan, "Hydrodynamic coupling in microbially mediated fracture mineralisation: formation of self-organised flow channels," Water Resources Research, vol. 50, no. 1, pp. 1-16, 2013.

[36] D. J. Tobler, J. M. Minto, G. E. Mountassir, R. J. Lunn, and V. R. Phoenix, "Microscale Analysis of fractured rock sealed with microbially induced $\mathrm{CaCO}_{3}$ precipitation: influence on hydraulic and mechanical performance," Water Resources Research, vol. 54, no. 10, pp. 8295-8308, 2018.

[37] C. Wu, J. Chu, S. Wu, and W. Guo, "Quantifying the permeability reduction of biogrouted rock fracture," Rock Mechanics and Rock Engineering, vol. 52, no. 3, pp. 947-954, 2018.

[38] C. Wu, J. Chu, S. Wu, and Y. Hong, “3D characterization of microbially induced carbonate precipitation in rock fracture and the resulted permeability reduction," Engineering Geology, vol. 249, pp. 23-30, 2019.

[39] N. Barton and V. Choubey, "The shear strength of rock joints in theory and practice," Rock Mechanics, vol. 10, no. 1-2, pp. 1-54, 1977.

[40] V. Achal, A. Mukherjee, and M. S. Reddy, "Microbial concrete: way to enhance the durability of building structures," Journal of Materials in Civil Engineering, vol. 23, no. 6, pp. 730-734, 2011.

[41] K. O. Kohnhauser, Introduction to Geomicrobiology, Blackwell Publishing, Malden, MA, USA, 2007. 